\title{
Impact of Working and Non - Working Mothers on Development of their Children in Madhya Pradesh
}

\author{
Vippa Dhingra ${ }^{1}$ and Sarika Keswani ${ }^{2}$ \\ Assistant Professor, Amity Business School, Amity University, Madhya Pradesh, Maharajpura Dang, Gwalior \\ $(M P)^{l}$. \\ Assistant Professor, Gitarattan International Business School, Rohini, New Delhi ${ }^{2}$ \\ vippa.dhingra@gmail.com,sarika.keswani83@gmail.com
}

\begin{abstract}
Parenting is the important responsibility that is considered as backbone of child's success. In Indian society child rearing is considered as the responsibility of mothers. This responsibility is till adolescent age of child which is considered very critical if not given proper care. Thus supervision of mother for child's behavioral development, attitude building and learning are key factors which mother are required to emphasize on. The study is based on impact of working and non-working mothers on development of their children keeping in consideration all these factors. Proper and fulltime supervision by non working mothers help children to properly learn and develop positive attitude. Working mothers are able to fulfill not only the financial needs of their children but also are able to inculcate self decision making due to less supervision and make their children more confident. The study is targeted to both working and non-working moms on gender attitude and social learning, behavioral factors and domestic engagement to 600 mothers in Madhya Pradesh. Regression analysis shows that there is there is positive impact of all these factors on child's well being. The education of mother also plays important role in gender attitude, social learning and domestic engagement. Thus working women are found to have positive impact on their children's well being as compared to non-working mothers.
\end{abstract}

Keywords: Gender attitude, behavioral change, domestic engagement, social learning.

\section{INTRODUCTION}

Parenting is considered as important factor for child's development and well being. It is mother who is considered responsible for developing positive attitude, behavior and inculcating positive abilities in their children. This helps the children to have an understanding of right and wrong and to become good and successful human beings. Working women thus have a tough task of professional obligation along with taking care and nurturing their children from early age to adolescent. Although they are able to fulfill financial needs of their children but, still they are not able to give as much time and care as given by non-working mothers. This make children self dependent in their day-to-day task, self confident and good decision makers. As children observe their father's too, supporting their mother's in household chores, they too start doing same. Domestic engagement is given equal importance by son's of such working mothers. This positive gender attitude and social learning helps them in their future live as well.

The study focuses on gender attitude \& social learning and behavioral factors and domestic engagement as these factors lead to children's well being. Education also affects all these factors and thus its impact is also analyzed in the study. Working mothers as well as non-working mothers both have different strengths in rearing their children and have been evaluated based on these variables.

\section{LITERATURE REVIEW}

\section{Gender Attitude and Social Learning}

Previous studies show that gender attitude in children is developed on observing their parents division of gender labor, household work and paid labor. This gender behavior among their children is developed based on family division of labor. (Cunningham, 2001). He suggested that parent's ideologies and division of labor in home develops children gender attitude. Children of working mother have more positive gender attitude as they share family duties with their parents from childhood. (Davis and Greenstein, 2009, Fernández et al. 2004).

Mostly mother guides their children in developing gender attitude and behavioral models of skills (Beller, 2009). Children learn non-traditional activities from their parents such as girls going out for work and boys doing households chores (Gupta, 2006; Olivetti et al., 2016). Children's' behavioral capacities are more influenced by their parents in comparison to friends, teachers and another relatives (Bandura, 1977 and Basow and Howe, 1979). It is said that according to social learning theory, not only behavior, even children's occupational preferences are also strongly influenced by their parents' occupation (Carmichael, 2000, Emran and Shilpi, 2011, Miller and Hayes, 1990). Previous studies have shown a strong correlation between the professional status of the mother and the occupation selected by 
her daughters (Boyd, 1985, DiPietro and Urwin, 2003, Emran and Shilpi, 2011, Hayes, 1987, Stevens and Boyd, 1980). The use of the mother in her daughters 'career choice was superior to the influence of the parents' educational status (Stevens and Boyd, 1980: 1992).

\section{Behavioral Factors}

Well being of children and their behavior may also be influenced by the employment of their mothers. Working mothers possibly develop more sense of responsibilities and independence in their children. However, long working hours of mothers may deprive children of their emotional support, and this in turn may impact development of children in a negative way (Lerner and Ree Noh, 2000). But working mothers bring additional income resources for the family which may be utilized for educational and recreational purposes of the children ( Heckman, 2000). This, in turn may also reduces the stress in the family and develop strong relationships between children and parents (Guo and Harris, 2000). Working mothers try to spend time with their children in more productive manner. Working mothers serve as a model to promote the independence of their children (Aughinbaugh and Gittleman, 2004

\section{Domestic Engagement}

Division of household workloads between parents also encourages children to engage more in domestic chores. This tendency then continues even when the children become parent (Gupta, 2006). Involvement of male children in domestic activities also leads to infuse respect and support for females who carry out such tasks on regular basis. Studies have shown that social learning generational influences are found in those male children whose fathers also take part in domestic chores (Cunningham, 2001). The labour force participation rates among mothers in various societies in different countries are also varied (Miani and Hoorens, 2014). The cultural components are developed in children when they observe their mothers being employed (Hook, 2006). Studies have shown that such societal models influence the daughter's employment results as per their mothers' employments. The mother's employment also affects the involvement of their children in household chores.

\section{Model 1}

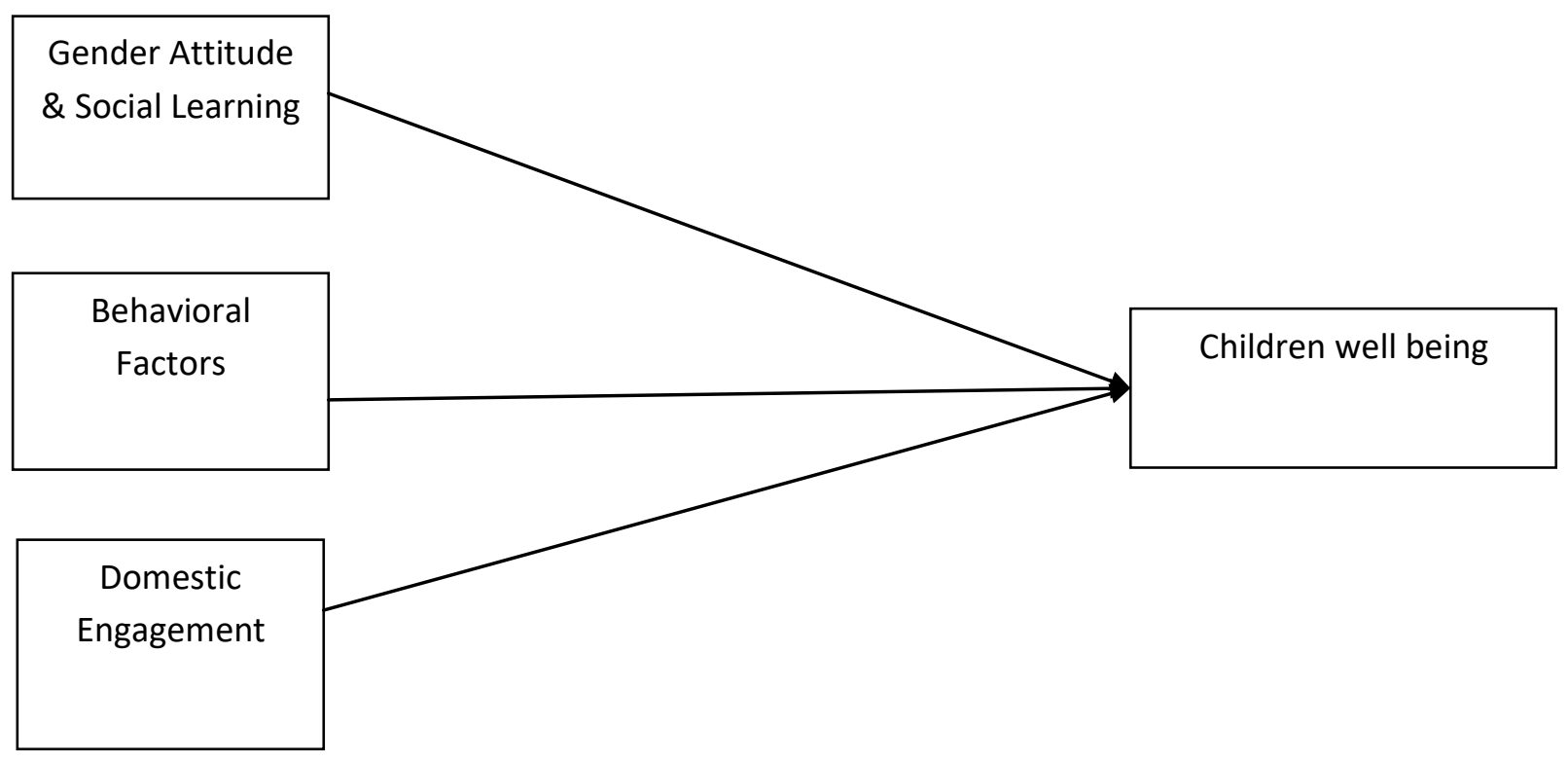

i) To investigate the impact of gender attitude and social learning, behavioral factors and domestic engagement on children well being.

ii) To determine the differential impact of working and non-working mothers in gender attitude training and social learning, behavioral factors and domestic engagement.

iii) To study the impact of mother's education on the gender attitudes \& social learning, behavioral factors and domestic engagement. 


\section{Hypothesis}

H1: There is no significant impact of gender attitude and social learning, behavioral factors and domestic engagement on children well being.

$\mathrm{H} 2$ : There is no significant difference between the children of the working and non-working mothers in the formation of gender and social learning, behavioral factors and domestic engagement.

H3: There is no significant impact of the mother's education on children's gender attitudes \& social learning, behavioral factors and domestic engagement.

\section{Method:}

The study is based on descriptive research of survey type. For the study 600 female non-working and working were taken from five major cities in Madhya Pradesh. A self- structured questionnaire was administered on both working and non-working mothers of children. The questionnaire is based on the questionnaire of personal attributes (Spence, Helmreich and Stapp, 1974) on a likert scale ranging from a strongly agree to strongly disagree on a scale of 1 to 5. The respondents are mothers (Working or non-working) who give scores to their children on this scale. Children well being is taken as dependent variable and gender attitude and social learning, behavioral factors and domestic engagement are taken as independent variables.

\section{Results and Discussions:}

To study the impact of gender attitude and social learning, behavioral factors and domestic engagement on well being in their lives was analyzed using regression analysis.

Table 1

Variables Entered / Removed ${ }^{\mathrm{a}}$

\begin{tabular}{|l|c|c|c|}
\hline $\begin{array}{l}\text { Mode } \\
1\end{array}$ & Variables Entered & $\begin{array}{l}\text { Variables } \\
\text { Removed }\end{array}$ & Method \\
\hline 1 & Gender Attitude and Social Learning, Behavioral Factors, Domestic Engagement &. & Enter \\
\hline
\end{tabular}

a. Dependent Variable: Children well being

b. All selected variables entered.

Table 2

Model Summary

\begin{tabular}{|l|c|c|c|c|}
\hline Model & R & R Square & Adjusted R Square & Std. Error of the Estimate \\
\hline 1 & $.739^{\mathrm{a}}$ & .546 & .543 & .53115 \\
\hline
\end{tabular}

a. Predictors: (Constant) Gender Attitude and Social Learning, Behavioral Factors, Domestic Engagement

Table 3 ANOVA ${ }^{\mathrm{a}}$

\begin{tabular}{|ll|c|c|c|c|c|}
\hline Model & & Sum of Squares & Df & Mean Square & F & Sig. \\
\hline \multirow{3}{*}{1} & Regression & 202.014 & 3 & 67.338 & 238.684 & $.000^{\mathrm{b}}$ \\
& Residual & 168.144 & 596 & .282 & & \\
& Total & 370.158 & 599 & & & \\
\hline
\end{tabular}

a. Dependent Variable: Children well being

b. Predictors: (Constant): Gender Attitude and Social Learning, Behavioral Factors, Domestic

Engagement

Table 4

Coefficients $^{\mathrm{a}}$

\begin{tabular}{|ll|c|c|c|c|c|}
\hline Model & \multicolumn{2}{|c|}{$\begin{array}{c}\text { Unstandardized } \\
\text { Coefficients }\end{array}$} & $\begin{array}{c}\text { Standardized } \\
\text { Coefficients }\end{array}$ & \multirow{2}{*}{ Sig. } & \\
\cline { 3 - 5 } & & $\mathrm{B}$ & Std. Error & Beta & & \\
\hline \multirow{4}{*}{1} & .045 & .087 & & .519 & .604 \\
& (Constant) & .325 & .059 & .266 & 5.549 & .000 \\
& Gender Attitude and Social Learning & .325 & .060 & .340 & 7.295 & .000 \\
& Behavioral Factors & .436 & .060 & .231 & 6.600 & .000 \\
\hline
\end{tabular}

a. Dependent Variable: Children well being 
Table 2 shows that there is $54.3 \%$ of impact of gender attitude and social learning, behavioral factors and domestic engagement on children well being. Table 4 shows that there is a significant impact of gender attitudes and social learning, behavioral learning and domestic participation on the well-being and success of children, since all have a significant value $(.000)$ is less than the level of significance i.e. 0.05 . The beta value shows that of gender attitude and social learning, behavioral factors and domestic engagement $32.5 \%, 43.6 \%$ and $22.4 \%$ impact on positive development of children well being. Thus $\begin{array}{llll}\text { hypothesis } & 1 & \text { is }\end{array}$

Table 5

Group Statistics

\begin{tabular}{|ll|c|c|c|c|}
\hline & Status & $\mathrm{N}$ & Mean & $\begin{array}{c}\text { Std. } \\
\text { Deviation }\end{array}$ & $\begin{array}{c}\text { Std. Error } \\
\text { Mean }\end{array}$ \\
\hline \multirow{2}{*}{ Gender Attitude and Social Learning } & Working & 353 & 2.3269 & .68406 & .03641 \\
& Non working & 247 & 2.2146 & .57399 & .03652 \\
Behavioral Factors & Working & 353 & 2.3144 & .65268 & .03474 \\
\multirow{3}{*}{ Domestic Engagement } & Non working & 247 & 2.2558 & .55351 & .03522 \\
& Working & 353 & 2.2854 & .83459 & .04442 \\
& Non working & 247 & 2.2986 & .77050 & .04903 \\
\hline
\end{tabular}

Table 6

Independent Samples Test

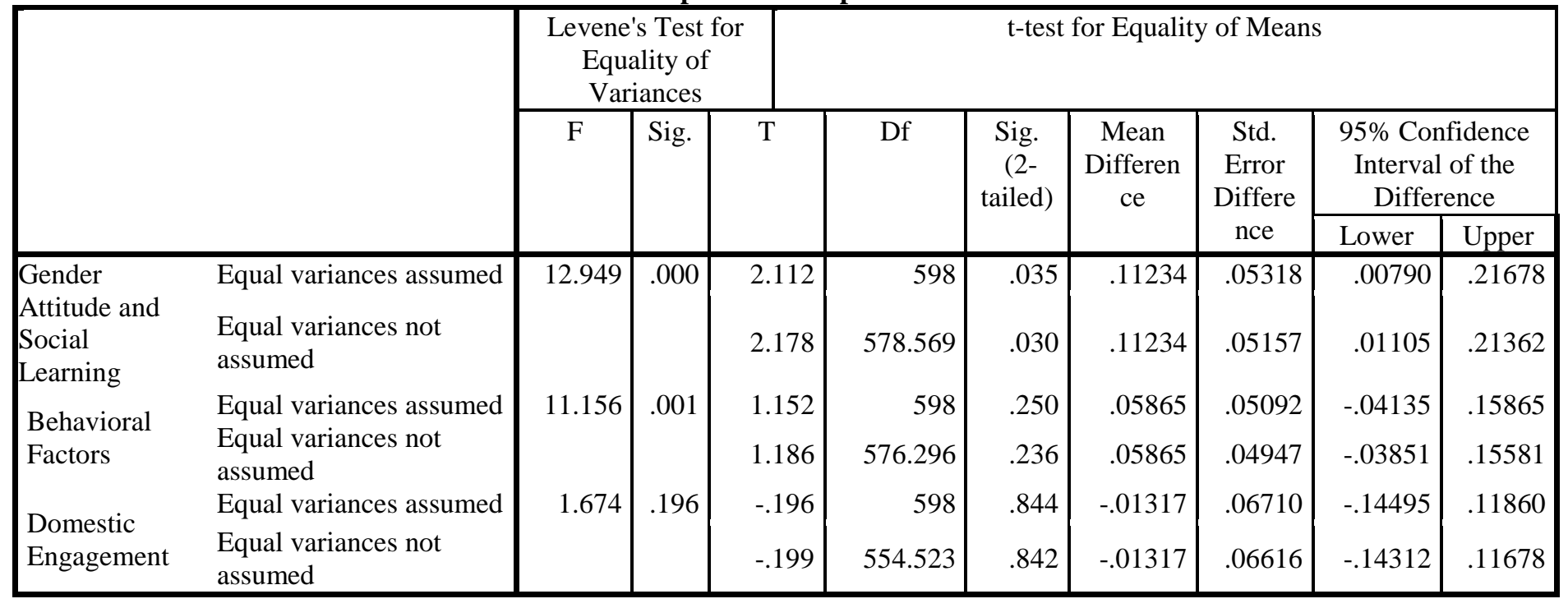

Table 5 shows the result of independent t- test of 353 working mothers and 247 non-working mothers. Levene's Test showed in table 6 shows that gender attitude and social learning has $\mathrm{p}$ value $(.000)<0.05$ rejecting the assumption of equal variance. Therefore, it is observed that there is an impact of working and non-working mothers in the definition of gender attitudes and social learning of children. Likewise, a difference in the behavioral factors of the children of working and non-working mothers as $\mathrm{p}$ value $(.001)<0.05$ rejecting the assumption of equal variance. On the other hand impact of domestic engagement factor has no impact on children of working and non-working mothers. Thus hypothesis 2 is rejected.

Table 7 shows that there is significant impact of mother's education on domestic engagement of their children in life as $\mathrm{F}$ value $=5.030$ where $(0.01$ $<0.05)$ the value of $\mathrm{p}$ is lower than the significance level of 0.05 . Therefore, education is likely to have an impact on the relationship. Thus, hypothesis 3 is rejected. 
International Journal of Research in Advent Technology, Vol.7, No.3, March 2019

E-ISSN: 2321-9637

Available online at www.ijrat.org

Table 7 - Mother's Education

ANOVA

\begin{tabular}{|ll|c|c|c|c|c|}
\hline & & $\begin{array}{c}\text { Sum of } \\
\text { Squares }\end{array}$ & Df & $\begin{array}{c}\text { Mean } \\
\text { Square }\end{array}$ & F & Sig. \\
\hline Gender Attitude and & Between Groups & 1.682 & 4 & .421 & 1.017 & .398 \\
Social Learning & Within Groups & 245.914 & 595 & .413 & & \\
& Total & 247.596 & 599 & & & \\
Behavioral Factors & Between Groups & 2.564 & 4 & .641 & 1.708 & .147 \\
& Within Groups & 223.251 & 595 & .375 & & \\
& Total & 225.815 & 599 & & \multirow{3}{*}{0.030} & .001 \\
& Between Groups & 12.797 & 4 & 3.199 & 5.030 \\
Domestic Engagement & Within Groups & 378.452 & 595 & .636 & & \\
& Total & 391.250 & 599 & & & \\
\hline
\end{tabular}

Table 8

Multiple Comparisons

Scheffe

\begin{tabular}{|c|c|c|c|c|c|c|c|}
\hline \multirow[t]{2}{*}{ Dependent Variable } & \multirow[t]{2}{*}{ (I) Occupation } & \multirow[t]{2}{*}{ (J) Occupation } & \multirow{2}{*}{\begin{tabular}{|c} 
Mean \\
Difference \\
(I-J)
\end{tabular}} & \multirow[t]{2}{*}{ Std. Error } & \multirow[t]{2}{*}{ Sig. } & \multicolumn{2}{|c|}{$\begin{array}{l}\text { 95\% Confidence } \\
\text { Interval }\end{array}$} \\
\hline & & & & & & $\begin{array}{l}\text { Lower } \\
\text { Bound }\end{array}$ & $\begin{array}{l}\text { Upper } \\
\text { Bound }\end{array}$ \\
\hline \multirow{20}{*}{$\begin{array}{l}\text { Gender Attitude and Social } \\
\text { Learning }\end{array}$} & \multirow{4}{*}{$\begin{array}{l}\text { Primary } \\
\text { School }\end{array}$} & Senior School & -.00351 & .07209 & 1.000 & -.2263 & .2192 \\
\hline & & Graduation & -.01696 & .07864 & 1.000 & -.2599 & .2260 \\
\hline & & Post Graduation & -.01119 & 09987 & 1.000 & -.3198 & .2974 \\
\hline & & Others & -.13989 & .07781 & .520 & -.3803 & .1005 \\
\hline & \multirow{4}{*}{ Senior School } & Primary School & .00351 & .07209 & 1.000 & -.2192 & .2263 \\
\hline & & Graduation & -.01345 & .08038 & 1.000 & -.2618 & .2349 \\
\hline & & Post Graduation & -.00768 & .10125 & 1.000 & -.3205 & .3052 \\
\hline & & Others & -.13638 & .07957 & .569 & -.3822 & .1095 \\
\hline & \multirow{4}{*}{ Graduation } & Primary School & .01696 & .07864 & 1.000 & -.2260 & .2599 \\
\hline & & Senior School & .01345 & .08038 & 1.000 & -.2349 & .2618 \\
\hline & & Post Graduation & .00577 & .10601 & 1.000 & -.3218 & .3333 \\
\hline & & Others & -.12293 & .08554 & .724 & -.3872 & .1414 \\
\hline & \multirow{4}{*}{$\begin{array}{l}\text { Post } \\
\text { Graduation }\end{array}$} & Primary School & .01119 & .09987 & 1.000 & -.2974 & .3198 \\
\hline & & Senior School & .00768 & .10125 & 1.000 & -.3052 & .3205 \\
\hline & & Graduation & -.00577 & .10601 & 1.000 & -.3333 & .3218 \\
\hline & & Others & -.12870 & .10540 & .828 & -.4544 & .1970 \\
\hline & \multirow{4}{*}{ Others } & Primary School & .13989 & .07781 & .520 & -.1005 & .3803 \\
\hline & & Senior School & .13638 & .07957 & .569 & -.1095 & .3822 \\
\hline & & Graduation & .12293 & .08554 & .724 & -.1414 & .3872 \\
\hline & & Post Graduation & .12870 & .10540 & .828 & -.1970 & .4544 \\
\hline \multirow{8}{*}{ Behavioral Factors } & \multirow{4}{*}{$\begin{array}{l}\text { Primary } \\
\text { School }\end{array}$} & Senior School & -.02033 & .06869 & .999 & -.2326 & .1919 \\
\hline & & Graduation & .04215 & .07492 & .989 & -.1894 & .2737 \\
\hline & & Post Graduation & -.02513 & .09516 & .999 & -.3192 & .2689 \\
\hline & & Others & -.15578 & .07414 & .354 & -.3849 & .0733 \\
\hline & \multirow{4}{*}{ Senior School } & Primary School & .02033 & .06869 & .999 & -.1919 & .2326 \\
\hline & & Graduation & .06248 & .07658 & .955 & -.1742 & .2991 \\
\hline & & Post Graduation & -.00479 & .09647 & 1.000 & -.3029 & .2933 \\
\hline & & Others & -.13544 & .07581 & .527 & -.3697 & .0988 \\
\hline
\end{tabular}


International Journal of Research in Advent Technology, Vol.7, No.3, March 2019

E-ISSN: 2321-9637

Available online at www.ijrat.org

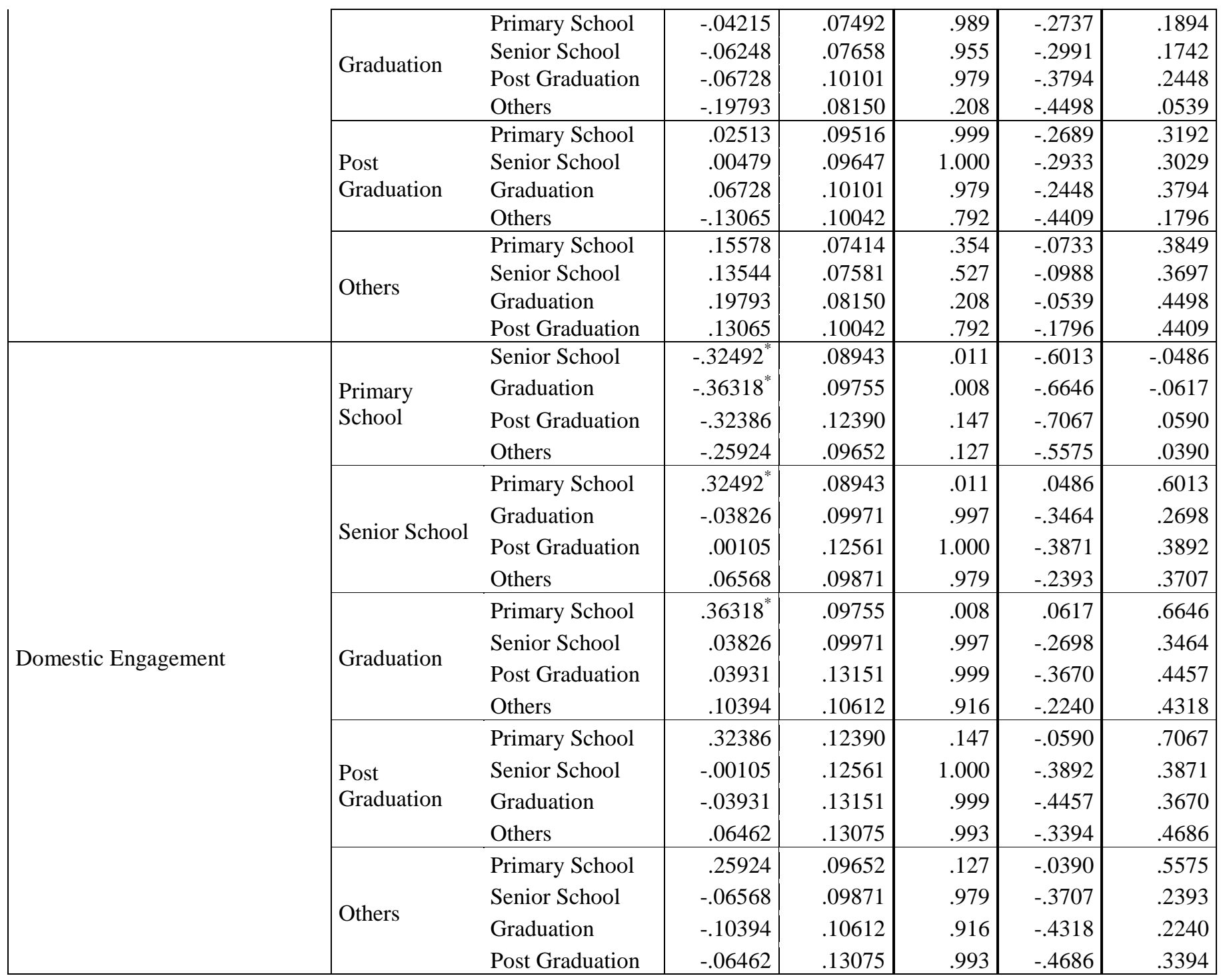

*. The mean difference is significant at the 0.05 level.

\section{DISCUSSION}

Thus, it is observed that there is a difference in the development of the children of working mothers compared to mothers who do not work in the development of social and gender learning, behavioral factors and domestic engagement to the well-being of children. Table 6 shows that there is impact of all these factors in development of well being of children as all factors are significant. Also there is difference in children's development of gender attitude and social learning and behavioral factors of working and non-working mother's (table 6) which is due to difference in supervision patterns on mothers on their children.

There is no such impact on domestic engagement. Working mother's education level plays an important role on domestic engagement of children (table 7). Also education level of mother has a significance impact in involving children in household work.

\section{CONCLUSION AND SUGGESTION:}

On the basis of analysis it could be concluded that the beta value shows that of gender attitude and social learning, behavioral factors and domestic engagement $32.5 \%, 43.6 \%$ and $22.4 \%$ impact on positive development of children well being. Thus hypothesis 1 is rejected.

Result of independent t- test is for 353 working mothers and 247 non-working mothers. Levene's Test showed in table 6 shows that gender attitude and social learning has $p$ value $(.000)<0.05$ rejecting the 
International Journal of Research in Advent Technology, Vol.7, No.3, March 2019

E-ISSN : 2321-9637

Available online at www.ijrat.org

assumption of equal variance. Therefore, it is observed that there is an impact of working and nonworking mothers in the definition of gender attitudes and social learning of children. Likewise, a difference in the behavioral factors of the children of working and non-working mothers is observed as $\mathrm{p}$ value $(.001)<0.05$ rejecting the assumption of equal variance. On the other hand impact of domestic engagement factor has no impact on children of working and non-working mothers. Thus hypothesis 2 is rejected.

ANOVA results shows that there is significant impact of mother's education on domestic engagement of their children in life as $\mathrm{F}$-value $=5.030$ where $(0.01$ $<0.05)$ the value of $\mathrm{p}$ is lower than the significance level of 0.05 . Therefore, education is likely to have an impact on the relationship. Thus, hypothesis 3 is rejected.

Thus it could be concluded that children of working and non-working mothers vary on all three factors gender attitude \& social learning, behavioral factors and domestic engagements. Mother's education also affects child's development and well being. Results suggest that working women are able to build positive gender attitude and make their children more independent and self assured. Working with less supervision makes their children good decision makers and inculcate confidence to face problems in life. Performing household work make them positive towards gender ideologies and domestic engagement. They give equal importance to females and their wives in future also with such values.

The study suggests that working mothers should try to spend quality time with their children along with fulfilling their financial needs. The study has not analyzed initial years of child which can have some negative impact on their children development. Thus it could be taken as future scope of this study.

\section{REFERENCES}

[1] Aughinbaugh, A. and Gittleman, M. (2004) Maternal employment and adolescents risky behaviour. Journal of Health Economics, 4, 815-838.

[2] Bandura, A. (1977). Self-efficacy: Toward a unifying theory of behavioral change. Psychological Review, 84, 191-215.

[3] Berger L, Brooks-Gunn J, Paxson C, Waldfogel J. First-year maternal employment and child outcomes: differences across racial and ethnic groups. Child Youth Serv Rev. 2008;30:365-387.

[4] Bianchi, S. M. (2000) Maternal Employment and Time With Children: Dramatic Change or Surprising Continuity? Demography, 37, 401-414.

[5] Cunningham, Mick. 2001. "The Influence of Parental Attitudes and Behaviors on Children's Attitudes toward Gender and Household Labor in Early Adulthood." Journal of Marriage and Family 63 (1): 111-122.

[6] Davis, Shannon and Theodore Greenstein. 2009. "Gender Ideology: Components, Predictors, and Consequences." Annual Review of Sociology 35: 87-105.

[7] Davis, Shannon and Jeremiah Wills. 2010. "Adolescent Gender Ideology Socialization: Direct and Moderating Effects of Fathers' Beliefs." Sociological Spectrum: Mid-South Sociological Association 30 (5): 580-604.

[8] Gupta, Sanjiv. 2006. "The Consequences of Maternal Employment during Men's Childhood for their Adult Housework Performance." Gender \& Society 22 (1): 6086.

[9] Guo, G. and Harris, K. M. (2000) The Mechanisms Mediating the Effects of Poverty on Children's Intellectual Development. Demography, 37, 431-447.

[10] Kostiainen, E., Martelin, T., Kestila, L., Martikainen, P. and Koskinen, S. (2009) Employee, partner, and mother: woman's three roles and their implications for health. Journal of Family Issues 30, 1122-1150.

[11] Lerner, J. V. and Ree Noh, E. (2000) Maternal Employment Influences on Early AdolescentDevelopment: A Contextual View. In Resilience Across Contexts: Family, Work, Culture and Community (eds R. Taylor and M. C. Wang). NJ: Lawrence Erlbaum Associates.

[12] Miani, C. \& S. Hoorens. 2014. 'Single parents and employment in Europe.' European Commission. As of 12 October 2016:

[13] http://ec.europa.eu/justice/genderequality/files/documents/140502_gender_eq uality_workforce_ssr3_en.pdf 